\title{
Albumin Determination with Bromocresol Purple: Imprecision, Comparison of Methods and Quality Control
}

\author{
By G. A. Harff \\ Academic Hospital, Free University, Department of Clinical Chemistry, Amsterdam, The Netherlands
}

(Received December 20, 1982/May 24, 1983)

Summary: The bromocresol purple methods for the determination of serum albumin on the Du Pont aca and on the KONE CD show very acceptable linear ranges and imprecision data. Comparison of methods showed good agreement between albumin determinations on the two instruments.

Human based quality control materials are required in order to monitor the accuracy of bromocresol purple methods, and to obtain results that are independent of method. or instrument. Assigned values in assayed controls and external quality control schemes based on the bromocresol green method are not suitable.

\section{Albuminbestimmung mit Bromkresolpurpur: Impräzision, Methodenvergleich und Qualitätskontrolle}

Zusammenfassung: Die Methoden zur Albuminbestimmung im Serum mit der Bromkresolpurpur-Reaktion auf dem Du Pont aca und dem KONE CD zeichnen sich durch einen weiten Meßbereich und hohe Präzision aus. Der Methodenvergleich zwischen diesen beiden Albuminbestimmungen ergab eine gute Úbereinstimmung.

Zur Richtigkeitskontrolle empfehlen sich Kontrollseren auf Humanbasis, wenn die Ergebnisse der Albuminbestimmung unabhängig von der Methode und dem Gerät sein sollen. Sollwerte und Ringversuche, denen ein mit Bromkresolgrün ermittelter Albuminwert zugrunde liegt, sind nicht auf die Bromkresolpurpur-Methode übertragbar.

\section{Introduction}

A new dye binding technique for the determination of albumin in serum, using bromocresol purple, was introduced by Louderback et al. (1). Automatisation was described by Pinnell \& Northam (2) for a continuous flow system, and its performance was compared with that of an established bromocresol green method. Haythorn \& Sheehan (3) increased the bromocresol purple concentration of $40 \mu \mathrm{mol} / \mathrm{l}$ used by Pinnell \& Northam to $80 \mu \mathrm{mol} / 1$ to obtain better linearity. Duggan \& Duggan (4) concluded that bromocresol purple has important advantages over bromocresol green in measuring albumin, namely improved specificity and higher reaction velocity. We have evaluated a new albumin method based on the bromocresol purple reaction for the Du Pont aca. We present the results of this evaluation and a comparison of the aca method with a similar procedure on the KONE CD.

\section{Materials and Methods}

Instruments

aca II (E.I. Du Pont de Nemours and Co., Wilmington, DE 19898, USA) KONE CD (KONE OY, SF-0232 Espoo, Finland). The KONE $C$ was instructed by program version 6.22 .

Automated Immuno Chemistry System (Beckman Instruments Inc., Brea, CA 92621, USA).

\section{Reagents}

Bromocresol purple $80 \mu \mathrm{mol}$, acetate buffered $\mathrm{pH} 5.2$, for albumin determination, product No.: 223425 , from BDH Chemicals Ltd., England. Albumin packs; concentration at measuring position: bromocresol purple $250 \mu \mathrm{mol} /$, acetate buffered $\mathrm{pH}$ 4.9. Lot No.: T2637A, from Du Pont, for use on the aca analyser.

Antibody to human albumin, lot No. C206019, from Beckman Instruments Inc..

Specimens

Calibration serum for KONE CD was Calibrate Automated Lock-in, Lot No. 1217049 and Lot No. 2261120 (lyophilised hu- 
man scrum), from General Diagnostics, USA. The Laurell rocket technique, with albumin standard product No. ORDT 02 purchased from Behringwerke AG, Marburg, FRG, was used to assay the albumin content of the Automated Lock-in calibration serum.

For the aca II bromocresol purple method, we used lyophilised human albumin calibrator Lot No. ILG761 from Du Pont, USA.

Calibrator for the Automated Immuno Chemistry System, lot No.: C204225, from Beckman Instruments.

Control sera were: Decision Level 1 Lot No. C009103, Decision Level 2 Lot No. C009104 and Decision Level 3 Lot No. C009105 from Beckman Instruments, USA. MONI-TROL I E Lot No. LTD-166 and MONI-TROL II E Lot No. PTD-65 from Merz and Dade, Switzerland. Normal Chemistry Control Lot No. IFD 690 from Du Pont, USA. OMEGA Lot No. 4833Y005BA from Travenol Laboratories, Belgium. Ortho Normal Lot No. 11T222, Ortho Abnormal Lot No. 12T322, Ortho Level I Lot No. E24X07A and Ortho Level II Lot No. E27X06A, from Ortho Diagnostics, Belgium. Precinorm U Lot No. 3-564 and Precipath U Lot No. 2-515 from Boehringer Mannheim, FRG. Seronorm Batch No. 151 from Nyegaard Co., Norway.

Fresh patients' sera from our hospital were used in the method comparison.

Procedure

All specimens to be analysed on the KONE CD were prediluted $10+1$ with physiological $\mathrm{NaCl}$ with the automatic dispenser KONE D. Diluted specimen $(25 \mu \mathrm{l})$ and bromocresol purple reagent $(475 \mu \mathrm{l})$ were added to a 24 'KONE' cuvette block. Calibration was performed with two samples of Automated Lock-in. After dispensing and mixing in a 24 cuvette block, the cuvette block was measured immediately on the colorimeter KONE $C$ at 600 $\mathrm{nm}$. For very lipaemic sera a serum blank was subtracted. No interference was caused by bilirubin in concentrations up to 250 $\mu \mathrm{mol} / \mathrm{h}$ measured without a serum blank.

On the aca II a bichromatic $(600 \mathrm{~nm}-540 \mathrm{~nm})$ measurement is performed to minimize the interference from lipaemia. Bilirubin interfered at concentrations above $350 \mu \mathrm{mol} / \mathrm{l}$. A filter balance was performed every day.

Protein electrophoresis was performed on cellulose acetate membranes, with Ponceau-S staining.

\section{Results and Discussion}

\section{Linearity}

To obtain specimens with increased albumin concentrations for the linearity study, human sera were frozen, and ice was removed during thawing. With these specimens, a linear analytical range between $0 \mathrm{~g} / \mathrm{l}$ and at least $80 \mathrm{~g} / \mathrm{l}$ was obtained for the KONE CD and the aca II.

\section{Imprecision}

Table 1 presents the data on within run imprecision for both bromocresol purple methods, calculated from duplicates of patients' samples. Both duplicates were analysed in the same run. Depending on the concentration range, the data were classified into three groups. Table 1 shows that the coefficient of variation is similar for both methods and remains relatively constant at different concentrations.
Tab. 1. Within run imprecision. Specimen: fresh human sera.

\begin{tabular}{lrllllll}
\hline & \multicolumn{3}{c}{ KONE CD } & \multicolumn{2}{c}{ aca II } \\
& $\mathrm{n}$ & $\begin{array}{l}\overline{\mathrm{x}} \\
(\mathrm{g} / \mathrm{l})\end{array}$ & $\begin{array}{l}\text { SD } \\
(\mathrm{g} / \mathrm{l})\end{array}$ & $\begin{array}{l}\mathrm{CV} \\
(\%)\end{array}$ & $\begin{array}{l}\overline{\mathrm{x}} \\
(\mathrm{g} / \mathrm{l})\end{array}$ & $\begin{array}{l}\text { SD } \\
(\mathrm{g} / \mathrm{l})\end{array}$ & $\begin{array}{l}\text { CV } \\
(\%)\end{array}$ \\
\hline Low & 33 & 27.41 & 0.27 & 1.00 & 26.67 & 0.33 & 1.24 \\
Mid & 33 & 36.49 & 0.29 & 0.78 & 35.15 & 0.42 & 1.19 \\
High & 34 & 43.47 & 0.31 & 0.72 & 42.39 & 0.55 & 1.30 \\
Total & 100 & 35.87 & 0.29 & 0.81 & 34.81 & 0.44 & 1.27 \\
\hline
\end{tabular}

To determine the imprecision between days, three control sera were analysed by the KONE CD and aca II on each of 22 consecutive days. Results are shown in table 2. Again, the coefficient of variation appears to be similar for both methods and rather independent of the albumin concentration. The precision clearly suffices for clinical needs.

Tab. 2. Between day imprecision. Specimen: quality control serạ.

\begin{tabular}{lllllll}
\hline & \multicolumn{2}{l}{ KONE CD } & \multicolumn{3}{c}{ acá II } \\
& $\begin{array}{llllll}\overline{\mathrm{x}} \\
(\mathrm{g} / \mathrm{l})\end{array}$ & $\begin{array}{l}\text { SD } \\
(\mathrm{g} / \mathrm{l})\end{array}$ & $\begin{array}{l}\mathrm{CV} \\
(\%)\end{array}$ & $\begin{array}{l}\overline{\mathrm{x}} \\
(\mathrm{g} / \mathrm{l})\end{array}$ & $\begin{array}{l}\text { SD } \\
(\mathrm{g} / \mathrm{l})\end{array}$ & $\begin{array}{l}\mathrm{CV} \\
(\%)\end{array}$ \\
\hline Ortho Level I & 26.71 & 0.36 & 1.35 & 25.74 & 0.48 & 1.86 \\
Ortho Level II & 38.86 & 0.51 & 1.31 & 38.54 & 0.77 & 2.00 \\
Decision Level 3 & 47.03 & 0.54 & 1.15 & 45.74 & 0.56 & 1.22 \\
\hline
\end{tabular}

\section{Quality control: Materials and programs}

To test the suitability of different quality control products, we determined the albumin concentration in 9 quality control sera in 4-fold analyses with both methods. As can be seen from table 3, the

Tab. 3. Method comparison. Specimen: control sera. Means of 4= fold analyses.

\begin{tabular}{|c|c|c|c|c|}
\hline & Basis & $\begin{array}{l}\mathrm{KO} \\
\mathrm{NE} \\
\mathrm{CD}\end{array}$ & $\begin{array}{l}\overline{\mathbf{x}} \\
(\mathrm{g} / \mathrm{l})\end{array}$ & $\begin{array}{l}\text { Reference } \\
\text { value for } \\
\text { bromo- } \\
\text { cresol= } \\
\text { greèn } \\
\text { mèthod } \\
(\mathrm{g} / \mathrm{l})\end{array}$ \\
\hline Decision Level 1 & humanan & 27.0 & 25.7 & 28 \\
\hline Decision Ĺevel 2 & human & 36.4 & 35.2 & 37 \\
\hline MONI-TROLIE & hưmàn & 35.9 & 37.7 & 47 \\
\hline MONI-TROL II Ė & humạạn & 31.2 & 30.5 & 33 \\
\hline Normal Chemistry Control & non human & 15.1 & 24.7 & 52 \\
\hline OMEGA & human & 45.8 & 44.4 & 45 \\
\hline Precinorm U & humànan & 30.2 & 29.5 & 32 \\
\hline Precipath U & humàn & 27.6 & 27.7 & 29.5 \\
\hline Seronorm & non humanan & 26.1 & 31.7 & 31 \\
\hline
\end{tabular}




\section{Erstmals das umfassende photometrische in vitro-Programm zur Schilddrüsendiagnostik von Boehringer Mannheim}

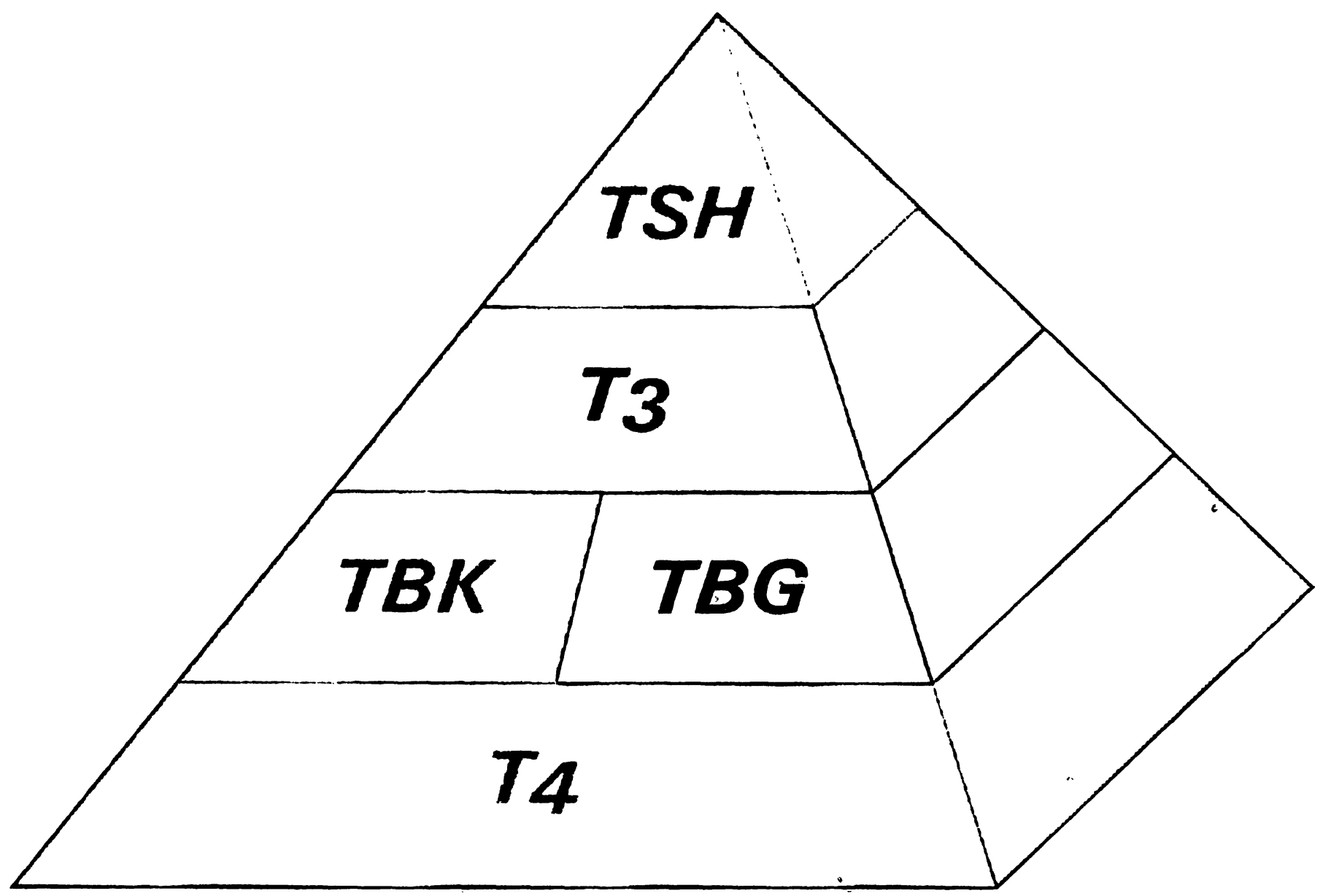

Für Ihr Labor Enzymimmunoassays in coated tube-Technik:

- hohe Spezifität, Empfindlichkeit und Präzision

- kurze Inkubationszeit (z. B. TSH 3 $\times 1$ Std.)

- einfache Handhabung

- lange Haltbarkeit der Reagenzien

- keine Radioaktivität

- automatische Auswertung mit: Enzymun-Test ${ }^{\circledR}$-System ES 11

Boehringer Mannheim bietet zur Schilddrüsendiagnostik erfahrene Fachberater, umfassende Informationsbroschüren und ein vielseitiges Fortbildungsprogramm.
Enzymun-Test ${ }^{\circledR}$ TBG

Bestell-Nr. 249432

Enzymun-Test ${ }^{\circledR}$ TBK

Bestell-Nr. 249416

Enzymun-Test ${ }^{\circledR}$ T3

Bestell-Nr. 204528

Enzymun-Test ${ }^{\circledR}$ T 4

Bestell-Nr. 204510

neu

Enzymun-Test ${ }^{\circledR}$ TSH

Bestell-Nr. 736082






\section{Fibrinogen \\ Recent Biochemical and Medical Aspects}

Proceedings · International Symposium

Max-Planck-Institute for Biochemistry

February 17-18, 1981, Martinsried/Munich, Germany

Editors A. Henschen $\cdot H$. Graeff - F. Lottspeich

$1982.17 \mathrm{~cm} \times 24 \mathrm{~cm}$. $X, 400$ pages. Numerous illustrations. Hardcover.

DM 135,-; approx. US \$61.50 ISBN 3110085437

This volume is a record of the contributions to the symposium entitled "Fibrinogen - Recent Biochemical and Medical Aspects." The object of this book is to review the progress in the biochemistry and pathobiochemistry of fibrinogen and to facilitate the exchange of ideas and experience between investigators from different fields.

Contents (Main chapters)

Physicochemical Aspects - Biochemical Aspects - Abnormàl Fibrinogens - Fibrinopeptide Determination - Fibrinogen - Fibrin Complexes - Fibrin(ogen) Degradation and Crosslinked Fibriñ Derivatives - Biological Effects of Low Molecular Weight Peptides and Interaction with other Proteolysis Author Index · Subject Index.

\section{Fibrinogen}

Structure - Functional Aspects - Metabolism

\section{Proceedings - Workshop on Fibrinogen}

May 12-14, 1982, Leiden, The Netherlands

Editors F. Haverkate - A. Henschen - W. Nieuwenhuizen - P. W. Straub

1983. $17 \mathrm{~cm} \times 24 \mathrm{~cm}$. XVI, 343 pages. Numerous illustrations.

Hardcover. DM 145,-; approx. US \$66.00 ISBN 3110089866

The scope of the conference was focused on research of fibrinogen and its derivatives and especially to its biochemical, physico-chemical and physiological aspects. The findings of the conference certainly will provide a firm basis for the development of new clinical applications.

Contents (Main chapters)

Physicochemical Aspects - Fibrinogen-Fibrin Conversion - Interaction with Divalent Cations - Abnormal Fibrinogens - Fibrinogen Derived Products in Vitro and in Vivo - Biosynthesis and Clearance. Other Physiological Aspects of Fibrinogen · Subject Index.

\section{Fibrinogen}

\section{Its Degradation Products, Structure and Function}

\section{Proceedings - Workshop on Fibrinogen}

July 9-10, 1983, Stockholm, Sweden

Editor A. Henschen

To be published in December 1983. $17 \mathrm{~cm} \times 24 \mathrm{~cm}$. Approx. 400 pages.

Numerous illustrations. Hardcover. ISBN 3110098067

Contents (Main chapters)

Fibrinogen and Fibrin-Structure - Biosynthesis - Fibrinogen-Fibrin Conversiōn - Platelet Fibrinogen . Genetically Abnormal Fibrinogens · Fibrinogen in Liver Disease - Interaction with Thrombin and some other Enzymes - Biologically Active Degradation Pिroducts · Immunological Aspects · Éffect on Plasminogen Activation - Interaction with Platelets and Endothelial Celis - Author- and Subject Index. 
agreement between the two methods is good, except in those cases where the quality control material is of non-human origin (Normal Chemistry Control, Seronorm).

When comparing the reference values for the bromocresol green method with the results with the bromocresol purple method, all human control sera show acceptable agreement, except MONI-TROL I E. The albumin concentration in the quality control products was also determined by protein electrophoresis and immunochemically with rate nephelometry. For MONI-TROL I E, protein electrophoresis gave a value of $46.3 \mathrm{~g} / \mathrm{l}$, whereas rate nephelometry gave $34.5 \mathrm{~g}$ /. Thus, MONI-TROL I E probably contains non-human albumin, causing a discrepancy between the results obtained with the two bromocresol purple methods and the reference value for the bromocresol green method. As a consequence, only human based quality control sera can be recommended for the bromocresol purple method, and a separate reference value for this method is required.

Difficulties similar to the above are encountered in external quality control programs. Thus, with the bromocresol purple method we were not able to participate in the Wellcome, the National Dutch or the regional Amsterdam quality control program. An improvement is expected from the introduction of human based control sera into the regional Amsterdam quality control program. The quality control program from Ortho Diagnostics is in principle suitable for the bromocresol purple method. At present only one other participant uses the bromocresol purple method. We have used the method routinely since January 1981 for serum albumin determination on the KONE CD.

The quality control data of Ortho control sera, using one analysis at each level each day, were used to calculate the mean and standard deviation per month (from January 1981 until December 1981 Ortho Normal and Ortho Abnormal were used; from December 1981 Ortho Level I and Ortho Level II were used). The means per month of Ortho Normal varied between $41.70 \mathrm{~g} / 1$ and $42.21 \mathrm{~g} /$; Ortho Abnormal between $36.49 \mathrm{~g} / \mathrm{l}$ and $36.86 \mathrm{~g} / \mathrm{l}$; Ortho Level I between $26.98 \mathrm{~g} / 1$ and $27.66 \mathrm{~g} / 1$; Ortho Level II between $39.08 \mathrm{~g} / \mathrm{l}$ and $39.83 \mathrm{~g} / \mathrm{l}$. The possible significance of differences between the given extreme values of means was examined by Student's $t$ test; Ortho Normal: $t=1.79,0.1>\mathrm{P}>0.05$; Ortho Abnormal: $\mathrm{t}=1.34,0.5>\mathrm{P}>0.1$; Ortho Level I: $\mathrm{t}=2.81$, $0.01>\mathrm{P}>0.001$; Ortho Level II: $\mathrm{t}=3.61$, $0.01>P>0.001$. During the period that Ortho Nor- mal and Ortho Abnormal were used, the degree of probability is larger than the conventional level of $5 \%$. The null hypothesis that there is no significant difference between the means is therefore somewhat likely. However, during the period that Ortho Level I and Ortho Level II were used the degree of probability is smaller than the conventional level of $5 \%$, so it is likely there is a significant difference between the means. It appeared that on March 9 of 1982 a new lot of bromocresol purple reagent was introduced, which caused a decrease of the level of the two controls! Excluding the three month period before the change the reagent lot, the means per month period of Ortho Level I varied between $26.98 \mathrm{~g} / 1$ and $27.39 \mathrm{~g} / \mathrm{l}$; Ortho Level II between $39.08 \mathrm{~g} / \mathrm{l}$ and $39.53 \mathrm{~g} /$; Ortho Level I: $\mathrm{t}=1.67,0.5>\mathrm{P}>0.1$; Ortho Level II: $t=2.38,0.05>P>0.02$. New photometer lamps and a change of the filter wheel had no detectable influence on the results.

The standard deviations (calculated for each monthly period) of Ortho Normal varied between $0.7 \mathrm{~g} / 1$ and $0.9^{\circ} \mathrm{g} / 1$; Ortho Abnormal between $0.5 \mathrm{~g} / 1$ and $0.8 \mathrm{~g} / 1$; Ortho Level I between $0.4 \mathrm{~g} / 1$ and $0.7 \mathrm{~g} / \mathrm{l}$; Ortho Level II between $0.5 \mathrm{~g} / \mathrm{l}$ and $0.8 \mathrm{~g} / \mathrm{l}$.

Except for the deviation of the monthly mean caused by a change of the lot No. of reagent, it can be concluded that the performance of the bromocresol purple method on the KONE CD over a two year period is acceptable.

\section{Comparison of methods}

Methods were compared according to the guidelines proposed by the American National Committee for Clinical Laboratory Standards (NCCLS, draft document PSEP 4 (5)). These guidelines are the basis for making a claim about inaccuracy. It prescribes that at least 100 fresh patients' samples should be analysed in duplicate by both the test method and the comparative analytical method. The experiment must cover a period of at least four days, which permits a maximum of 25 samples to be analysed in one day, or it can extend over a longer period of time if that is convenient for the evaluation study.

Over 20 days, 100 fresh patients' samples were analysed in duplicate on the aca II, the KONE CD and by protein electrophoresis. The results were analysed statistically with the NCCLS accuracy FORTRAN computer program.

The regression analysis between albumin obtained by protein electrophoresis ( $x$-axis) and the bromo- 


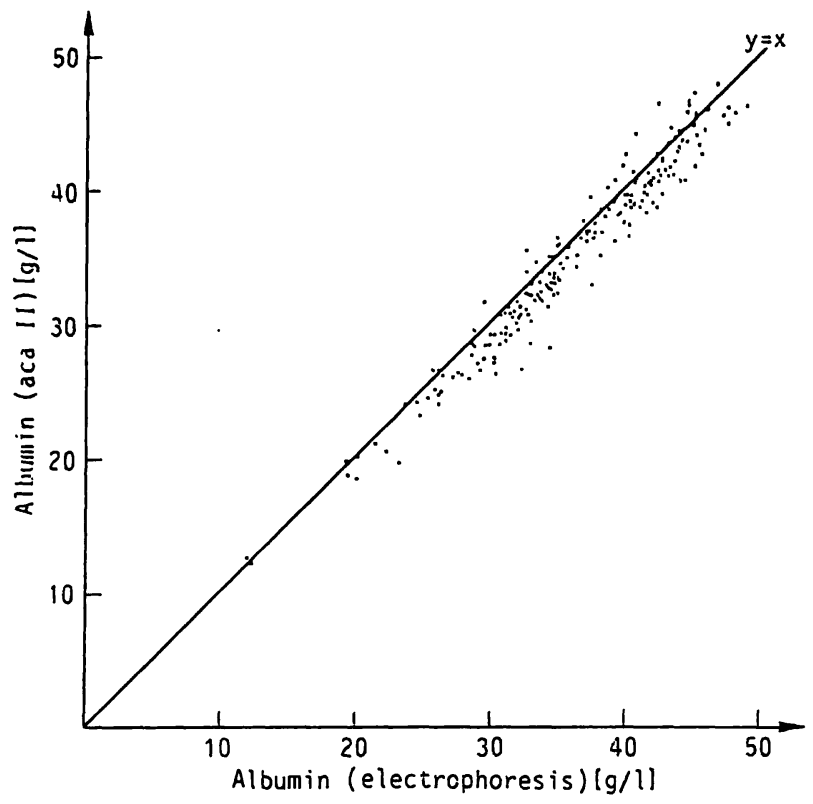

Fig. 1. Albumin comparison data for the results from protein electrophoresis ( $x$-axis) and the aca II (y-axis). The correlation shows $\mathrm{y}=-1.048+0.995 \mathrm{x} . \overline{\mathrm{x}}=36.05 \mathrm{~g} / \mathrm{l}$ and $\overline{\mathrm{y}}=$ $34.81 \mathrm{~g} /$. $S_{\mathrm{yx}}=1.55 \mathrm{~g} /$.

cresol purple aca II method (y-axis), (fig. 1), resulted in a slope of 0.995 (95\% confidence range: 0.964 to $1.025)$ and an intercept of $-1.048 \mathrm{~g} / 1$ (95\% confidence range: $-2.17 \mathrm{~g} / 1$ to $0.08 \mathrm{~g} / 1)$. Thus, a statistical difference between the methods was not observed. The standard error of estimate, $\mathrm{S}_{\mathrm{yx}}$, is 1.55 $\mathrm{g} / \mathrm{l}$. From the scatterplot of the residuals from the regression line it was concluded that the variance about the line does not change with concentration. With a second degree polynomial fit and appropiate F test, comparison of data from the two modifications was found to be linear $(F=1.74$, not significant).

The same patients' samples used for the regression analysis between protein electrophoresis and the bromocresol purple method on aca II, were at the same time also analysed on the KONE CD.

The regression analysis between the bromocresol purple method on the KONE CD ( $\mathrm{x}$-axis) and aca II

\section{References}

1. Louderback, A., Mealy, E. H. \& Taylor, N. A. (1968) Clin. Chem. 14, 793.

2. Pinnell, A. E. \& Northam, B. E. (1978) Clin. Chem. 24, 80-86.

3. Haythorn, P. \& Sheehan, M. (1979) Clin. Chem. 25, 194. 4: Duggan, J. \& Duggan, P. F. (1982) Clin. Chem. 28,
1407-1408.

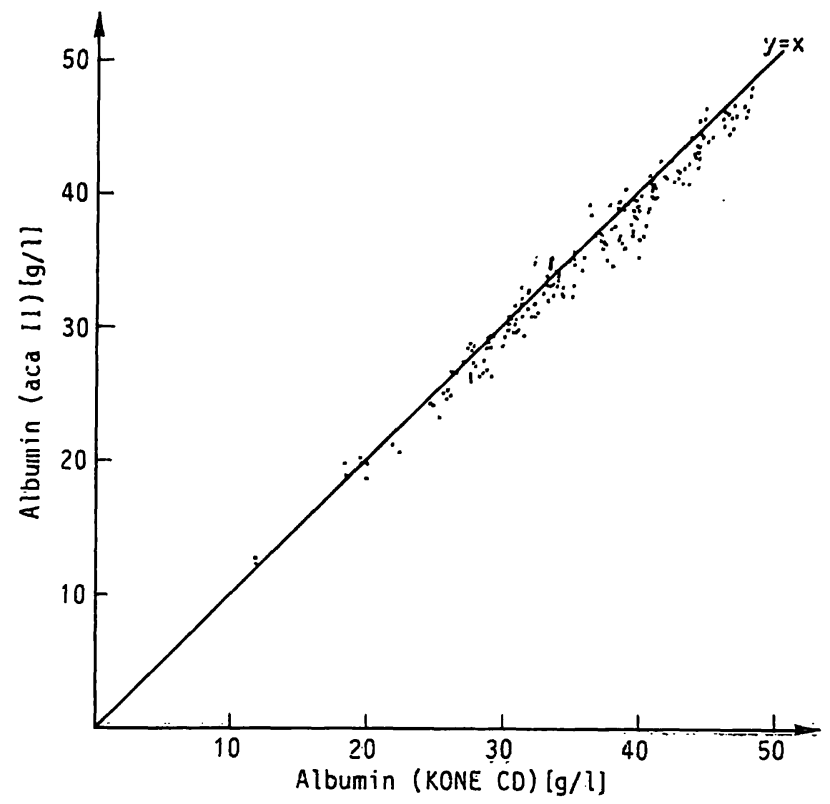

Fig. 2. Albumin comparison data for results from the KONE CD ( $x$-axis) and the aca II ( $y$-axis). The correlation shows $y=$ $-0.349+0.980 x . \bar{x}=35.87 \mathrm{~g} / 1$ and $\bar{y}=34.81 \mathrm{~g} / 1 . \mathrm{S}_{\mathrm{yx}}=$ $1.18 \mathrm{~g} /$.

(y-axis) showed a close correlation to each other (fig. 2). With a slope of 0.980 (95\% confidence range: 0.959 to 1.002$)$ and an intercept of $-0.349 \mathrm{~g} / 1(95 \%$ confidence range: $=1.158 \mathrm{~g} / \mathrm{l}$ to $0.460 \mathrm{~g} / \mathrm{l}$ ) a statistically significant difference between the methods could not be observed. The standard error of estimate, $S_{y x}$, is $1.18 \mathrm{~g} /$. From the scatterplot of the residuals from the regression line it was concluded that the variance about the line does not change with concentration. With a second polynomial fit and appropiate $\mathrm{F}$ test, comparison of data from the two modifications was found to be linear $(F \neq 4.82$, not signifịcant).

\section{Acknowledgements}

We thank E.J.P.M. de Moel, Medische Informatica, this university, for contribution of the NCCLS computer program, and Du Pont for supplying ALB-packs for the determination of albumin with the bromocresol purple method.
5. Draft Document: PSEP-4, Instrument Ëvaluation Subcommittee, Evaluation Protocols Area, National Committee for Cliṇical Laboratory Standards, 771 E Lancaster Ave., Villanova, PA 19085, United States of America, 1979.

ir. G. A. Harff

Department of Clinical Chemistry Academic Hospital, Free University De Boelelaan 1117 NL-1081 HV Amsterdam. The Netherlands 